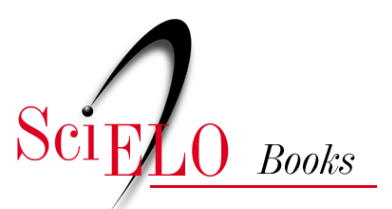

Editora da UESC

\title{
Capítulo I - Nem tudo era sergipano \\ a escrita do mito pioneiro e a invisibilização indígena nas origens de Itabuna
}

\author{
Ayalla Oliveira Silva
}

\section{SciELO Books / SciELO Livros / SciELO Libros}

SILVA, A.O. Nem tudo era sergipano: a escrita do mito pioneiro e a invisibilização indígena nas origens de Itabuna. In: Ordem imperial e aldeamento indígena: Camacãns, Gueréns e Pataxós do Sul da Bahia [online]. Ilhéus: Editus, 2018, pp. 34-83. ISBN: 978-85-7455-528-7.

https://doi.org/10.7476/9788574555287.0002.

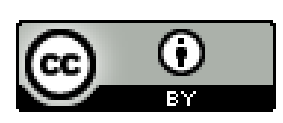

All the contents of this work, except where otherwise noted, is licensed under a Creative Commons Attribution $\underline{4.0 \text { International license. }}$

Todo o conteúdo deste trabalho, exceto quando houver ressalva, é publicado sob a licença Creative Commons Atribição 4.0. 
CAPÍTULO I 


\section{NEM TUDO ERA SERGIPANO: A ESCRITA DO MITO PIONEIRO E A INVISIBILIZAÇÃO INDÍGENA NAS ORIGENS DE ITABUNA}

No capítulo em questão, a proposta não é opor história e memória, mas tecer algumas observações acerca das operações concernentes a uma e a outra, especialmente no processo de construção da memória de origem de Itabuna, realizada por parte da elite política e intelectual da década de 1960, que evocou exclusivamente o pioneirismo dos seus antepassados, os migrantes sergipanos, para explicar o surgimento da cidade. Frisamos a possibilidade de escrituração de outras narrativas acerca da história e historicidade das origens de Itabuna; e propomos, nos capítulos seguintes, uma interpretação da história do sul da Bahia que abrigue os índios e as complexidades inerentes ao encontro dos diferentes atores no processo da colonização sul baiana.

Neste capítulo, recorreremos ao conceito de "representação", tal como discutido por Sandra Pesavento, em História e história cultural, a partir de seu diálogo com Marcel Mauss e Émile Durkheim ${ }^{1}$. Nossa proposta é

1 Cf. PESAVENTO, Sandra Jatahy. História e história cultural. 3. ed. Belo Horizonte: Autêntica, 2012, p. 40: Representar é, pois, fundamentalmente, estar no lugar de, é presentificação de um ausente; é um apresentar de novo, que dá a ver uma ausência. A ideia central é, pois, a da substituição, que recoloca uma ausência e torna sensível uma presença. 
analisar a escrita memorialista de Itabuna como processo de construção da representação identitária sergipana, no qual se opera uma ausência proposital de outros atores sociais nas origens da cidade, para supervalorizar a figura dos sergipanos como pioneiros do progresso regional.

Analisaremos a narrativa memorialista sob a perspectiva discursiva, nos termos de Foucault, porque, nos jogos de representação foi construída, para Itabuna, uma identidade sergipana; e transformada, essa narrativa, em mito, pelos usos da memória. ${ }^{2}$ Nesses termos, entendemos que "um mito não é necessariamente uma história falsa ou inventada; é, isso sim, uma história que se torna significativa na medida em que amplia o significado de um acontecimento individual (factual ou não), transformando-o na formalização, simbólica e narrativa, das autorrepresentações partilhadas por uma cultura [ou por um grupo]" ${ }^{3}$.

Entendemos que o conceito de discurso, presente em nosso estudo, dialoga, sem problema algum, com o conceito de representação, pois no jogo das representações da escrita da memória, as escolhas são construídas por práticas discursivas. A produção discursiva, para Foucault, envolve procedimentos de exclusão; ela "é ao mesmo tempo controlada, selecionada, organizada e redistribuída" ${ }^{4}$. Nesse sentido, o autor nos apresenta três procedimentos de exclusão da produção discursiva: a interdição, a separação e a vontade de verdade. É à última que Foucault dá

2 FOUCAULT, Michel. A ordem do discurso: aula inaugural no Collège de France, pronunciada em 2 de dezembro de 1970. 22. ed. São Paulo: Edições Loyola, 2012.

3 PORTELLI, Alessandro. "O massacre de Civitella Val di Chiana (Toscana, 29 de junho de 1944): mito e política, luto e senso comum". In: AMADO, Janaína; FERREIRA, Marieta de Moraes (Orgs.). Usos e abusos da história oral. 8 ed., Rio de Janeiro: FGV, 2006, p. 120-121.

4 FOUCAULT, Michel. Op., cit., p. 8. 
maior atenção. Nossa intenção é refletir sobre o desejo de dizer o verdadeiro incutido no discurso da escrita da memória de Itabuna. Vale ressaltar que, para Foucault, o discurso não é uma vontade de poder: ele é poder. Nas palavras do autor, "o discurso não é simplesmente aquilo que traduz as lutas ou os sistemas de dominação, mas aquilo porque, pelo que se luta o poder do qual nos queremos apoderar". ${ }^{5}$

Sendo assim, na construção da narrativa memorialista itabunense, quem detém a hegemonia da construção da memória também detém o poder de narrar a história das origens da cidade evidenciando a presença e a atuação dos antepassados sergipanos em detrimento de outros sujeitos, que desaparecem nessa narrativa. Em consequência disso, o discurso memorialista legitima o poder social e político dos herdeiros do cacau, diante da sociedade itabunense. Dessa forma, a construção de uma memória sergipana e a obliteração do índio, invisibilizado na narrativa, constituem-se no objeto de estudo deste capítulo.

\subsection{Os memorialistas e o seu lugar de fala}

Na década de 1960, no momento dos festejos em comemoração ao cinquentenário de emancipação política da cidade de Itabuna, alguns intelectuais e políticos da cidade se ocuparam em escrever a história de Itabuna, na qual os seus antepassados são evocados como os pioneiros e precursores de um presente cheio de progresso. Era o grande progresso que lhe conferia, aliás, o título de "Rainha da Bahia". Os escritos memorialistas foram os mais

5 FOUCAULT, Michel. Op., cit., p. 10. 
utilizados, posteriormente, por todos aqueles interessados em escrever sobre Itabuna e que, ao longo do tempo, tornaram-se porta-vozes da história da cidade, através da atualização da narrativa da memória construída nos anos 1960. Os livros fundadores da memória da cidade são: Documentário histórico ilustrado de Itabuna, de José Dantas de Andrade, de 1968; Terras de Itabuna, de Carlos Pereira Filho, de 1960; O jequitibá da Taboca, de Oscar Ribeiro Gonçalves, de 1960.

Inexistem informações satisfatórias sobre os autores acima citados, salvo algumas recolhidas em notas de livros ou fontes hemerográficas. Essa lacuna, produzida pela falta de trabalhos sobre os referidos autores, é importante registrar, pois embora suas obras sejam recorrentemente visitadas, não há um trabalho biográfico sobre os memorialistas da cidade, ou disponibilidade de informações mais precisas sobre eles.

Analisando as matérias do jornal Diário de Itabuna, da década de 1960, podemos recolher em uma página ou outra, algumas informações sobre a atuação social e política de alguns desses autores. O diretor e proprietário do jornal Diário de Itabuna, Ottoni Silva, por exemplo, em uma nota do dia 14 de maio de 1960, parabenizava o escritor e jornalista Carlos Pereira Filho, autor de Terras de Itabuna, e pontuava sua atuação em defesa dos interesses da lavoura do cacau, isto é, "[...] como procurador das associações que representam os interesses da lavoura cacaueira"6. A relevância conferida à Pereira Filho por Ottoni Silva fica em evidência quando do seu apelo para que a sociedade itabunense fizesse aquisição daquela obra. Em uma nota do mês de agosto do mesmo ano, fazendo menção ao lançamento

6 CEDOC; Diário de Itabuna, ano III, nº 698, 14 de maio de 1960. 
do livro de Pereira Filho, Ottoni conclama: "vá imediatamente a qualquer livraria local e adquira, por Cr\$150,00 apenas, o interessante livro Terras de Itabuna"7.

Entendemos que o apelo de Ottoni não era simplesmente para que a sociedade itabunense adquirisse o livro de Pereira Filho, era também, e mesmo principalmente, uma manifestação do desejo de tornar pública e legítima a história engendrada naquele livro. Pois, como bem observa Halbwachs, "a memória de uma sociedade se estende até onde pode - quer dizer, até onde atinge a memória dos grupos de que ela se compõe $e^{\prime}{ }^{8}$ Dessa forma, a narrativa da história do pioneiro de Itabuna se constituía no esforço da atualização da memória pioneira construída para a região Cacaueira, desde o início do século XX.

José Dantas de Andrade mantinha um programa de rádio, na Rádio Clube de Itabuna. Em nota no Diário de Itabuna, Ottoni ressaltava: "A história de Itabuna está sendo contada. Todos têm a palavra. Os contemporâneos de Tabocas vêm às nossas colunas e ao microfone da Rádio Clube de Itabuna, no programa do Dantinhas, para falar o que sabem" ${ }^{\prime \prime}$. É importante ressaltar que a Rádio Clube pertencia ao mesmo grupo do jornal Diário de Itabuna e ambos os veículos de comunicação da cidade, à época, estavam envolvidos na empreitada da construção da história de Itabuna.

Já Oscar Ribeiro Gonçalves era professor e foi prefeito da cidade de São Félix, no Recôncavo baiano. Ao que tudo indica, ele escreveu O Jequitibá da Taboca por encomenda,

7 CEDOC; Diário de Itabuna, Quarta-feira, 17 de agosto de 1960, Ano III, n 730, p. 4.

8 HALBWACHS, Maurice. A memória coletiva. São Paulo: Centauro, 2003, p. 105.

9 CEDOC; Diário de Itabuna, 16 de julho de 1960, ano III, nº 739, s/p. 
na ocasião das comemorações do cinquentenário de Itabuna ${ }^{10}$. O conteúdo da obra consiste no registro dos relatos orais de um antigo morador da cidade, Manoel Bonfim Fogueira.

A atuação dos intelectuais da década de 1960 nos órgãos de imprensa, seja falada ou escrita, permite perceber, na relação da narrativa memorialista com a imprensa, o esforço de construir uma história oficial e homogênea para Itabuna, pois os discursos da escrita da memória e a pauta de trabalho da imprensa da cidade, naquele ano, complementavam-se. Era interessante reproduzir, na imprensa, a versão narrada nos livros memorialistas, pois, dentre os demais meios de comunicação utilizados pelos intelectuais de Itabuna, o rádio, por exemplo, tinha um alcance abrangente, veiculava informações em todas as camadas da sociedade. Tal atuação na imprensa demonstra, ainda, como esses memorialistas circulavam social e politicamente, visto que os jornais eram importantes espaços de veiculação de ideologias e disputas políticas.

O jornal Diário de Itabuna foi fundado em 1957, tinha como diretor o jornalista Ottoni Silva e circulava no trecho Itabuna-Ilhéus e em outras cidades menores, como Itapé, Ibicaraí, Itapetinga, Buerarema, Juçari, Camacã, Coaraci e Banco Central ${ }^{11}$.

Como veremos no próximo tópico, a história e a política na região cacaueira guardavam relações muito estreitas,

10 Plínio de Almeida, no prefácio de O Jequitibá da Taboca, esclarecia que havia a possibilidade de que o leitor encontrasse "alguns descuidos" na obra [apresentada], em face do curto espaço de tempo que o autor teria tido para apresentar o livro: GONÇALVES, Oscar Ribeiro. O jequitibá da Taboca: ensaios históricos de Itabuna. Itabuna: Oficinas Gráficas da Imprensa da Bahia, 1960, p. 16.

11 RIBEIRO, Danilo Ornelas. Do fazer jornalístico às sociabilidades de elites: a construção da Itabuna moderna (1957-1964). Monografia. Universidade Estadual de Santa Cruz: Ilhéus, 2010, p. 18. 
e poderíamos até dizer que uma legitimava e referendava a outra. Nessa perspectiva, ressaltamos que o lugar de herdeiros dos precursores do cacau, no qual estavam inseridos os intelectuais e políticos envolvidos em escrever a história de Itabuna, na década de 1960, diz muito sobre a sua produção.

\subsection{A "civilização do cacau": a construção de uma me- mória coletiva}

Ao longo do século XX, o sul da Bahia foi se configurando, por meio da escrita da memória, da literatura, dos estudos acadêmicos e técnicos, no que Adonias Filho denominou de "civilização do cacau". Dessa maneira, a região assume uma identidade do cacau. Para Adonias Filho, a região guardava peculiaridades engendradas pela geografia, estrutura social e organização econômica, que lhe conferiam um caráter de unidade, denominada, por ele, de um "pequeno país". Uma civilização que, nos termos do autor, foi cunhada pela inter-relação de imigrantes estrangeiros e nacionais, negros e índios, resultando na "identidade grapiúna". Hoje, o termo grapiúna faz referência apenas aos itabunenses ${ }^{12}$.

Nas páginas seguintes deste tópico, nos ocuparemos em entender a construção da memória da "civilização do cacau". As disputas pela memória refletiam as disputas de poder político na região. Entender a construção da memória coletiva para a região cacaueira, engendrada ao

12 DANTAS, Robson Norberto. Entre a arte, a história e a política: Itinerários e representações da "ficção brasiliana" e da nação brasileira em Adonias Filho (1937-1976). Tese de doutorado. UNICAMP, Campinas: São Paulo, 2010, p. 180-181. 
longo do século $X X$, nos possibilita analisar a apropriação e acomodação dessa memória pelos intelectuais e políticos de Itabuna da década de 1960, com o fim de engendrar a construção da versão pioneira sergipana, que, por sua vez, explicaria as origens de Itabuna.

A análise da escrita memorialista da região cacaueira como uma construção coletiva se dá nos termos de Maurice Halbwachs, para quem toda memória é coletiva, já que a memória individual é penetrada pela memória coletiva. Halbwachs salienta que a construção da memória é possível porque o indivíduo evoca palavras e ideias exteriores a ele, tomadas de empréstimo do seu ambiente ${ }^{13}$. Em outras palavras, a memória de um indivíduo não é construída fora do tempo e do espaço; ao contrário disso, ela faz parte da memória do grupo social ao qual pertence.

Halbwachs observa que o grupo nacional do qual faço parte vivenciou uma série de acontecimentos acerca dos quais digo que me lembro, mas que conheci apenas através dos jornais ou do testemunho de quem os vivenciou diretamente: "quando os evoco, sou obrigado a me remeter inteiramente à memória dos outros, e esta não entra aqui para completar ou reforçar a minha, mas é a única fonte do que posso repetir sobre a questão"14. Também a memória que julgamos individual, com base em nossas próprias lembranças, tem como referência uma carga de informações culturais e sociais que as enquadra e, por isso mesmo, é coletiva. Nas palavras de Halbwachs, "a lembrança é uma imagem introduzida em outras imagens, uma imagem genérica transportada ao passado" ${ }^{15}$.

13 HALBWACHS, Maurice. Op., cit., p. 72.

14 Idem, ibidem.

15 Idem, p. 93. 
Mary Ann Mahony observa que, nas primeiras décadas do século $\mathrm{XX}$, motivado por diversos fatores, em nível nacional e internacional, houve o grande boom do cacau na região sul da Bahia, cujos principais expoentes foram as cidades de Ilhéus e Itabuna. Naquele momento, uma luta pela memória da região cacaueira, que muito tinha a ver com as disputas políticas, começou a ser travada entre uma aristocracia advinda dos bem nascidos, descendentes dos antigos senhores de engenho de Ilhéus, e as famílias ricas de Salvador, que passavam a investir em cacau, de um lado; e, de outro, os "novos ricos". Para Mahony, "os proprietários novos ricos [...] eram um grupo muito diferente [das famílias tradicionais de Ilhéus], dado que saíram das camadas baixas da sociedade"16. Tratava-se dos imigrantes e migrantes pobres, descendentes de índios e de escravos, que enriqueceram com a lavoura do cacau.

Para Mahony, o grande problema era a recusa da elite tradicional de Ilhéus em aceitar, na mesma classe social, aqueles que a ela se igualavam apenas em termos de riqueza, os novos ricos. Para a elite ilheense, aqueles homens, "no máximo, eram pouco mais do que uns lavradores caboclos ou mulatos e, na pior das hipóteses, ex-escravos arrogantes com dinheiro" ${ }^{17}$. Os novos ricos, ao mesmo tempo em que se ressentiam pela maneira como eram vistos e tratados pela elite aristocrática, sentiam-se explorados por ela e orgulhavam-se de contribuir para a riqueza do Estado. Somados todos esses aspectos sociais e políticos, "os novos ricos" passaram a

16 MAHONY, Mary Ann. Um passado para justificar o presente: memória coletiva, representação histórica e dominação política na região cacaueira da Bahia. Especiaria, v. 10, n. 18, jul-dez., 2007. p. 746.

17 Idem, p. 748. 
lutar, num jogo político e de memória, pela construção de sua identidade como elite. Contudo, diferentemente dos bem nascidos, eles iriam evocar um passado de humildade e de trabalho pioneiro, que lhes conferia o lugar de elite do cacau. A dupla batalha, pela busca de um lugar na política e de um lugar social na história da região, estava presente nos discursos políticos de um desses novos ricos: Antônio Pessoa.

Os novos ricos, no início do século XX, ambicionavam, sem sucesso, cargos de representação política na região, realidade que fazia emergir uma disputa política violenta entre pessoístas e adamistas (ambas as terminologias são utilizadas para designar os dois grupos rivais na política ilheense à época, representados por Antônio Pessoa e Domingos Adami Sá). No jornal A Gazeta de Ilhéus, de propriedade de Antônio Pessoa, este deixava em evidência que os seus inimigos políticos eram Domingos Adami Sá, Ernesto Sá Bittencourt Câmara e seus aliados ${ }^{18}$. No cenário dessas disputas políticas, o principal recurso utilizado era a memória pioneira da região do cacau que estava sendo construída. Em seus discursos, Pessoa apresentava a si e a seus correligionários como homens que enriqueceram com o suor do próprio trabalho e faziam o contraponto com seus adversários, apontando-os como ex-senhores de escravos e aristocratas:

A estratégia de Pessoa era brilhante: identificava seus aliados - os novos ricos - com os trabalhadores, pequenos produtores e novos migrantes na região, e seus inimigos - os Adami - com os aristocratas e ex-senhores de escravos que dominaram os lugares onde eles nasceram. ${ }^{19}$

18 MAHONY, Mary Ann. Op., cit., p. 751.

19 Idem, p. 752. 
Os novos ricos, em 1911, conseguem, enfim, obter ascensão política na região. Como bem frisa Mahony, naquele ano, em vista do declínio político das elites tradicionais baianas, Antônio Pessoa conseguiu se eleger para a Assembleia Legislativa do Estado e, no ano subsequente, por intermédio do governador da Bahia, J.J. Seabra, ele conseguiu também a Intendência de Ilhéus ${ }^{20}$. Aquele momento marcou a era dos novos ricos no poder político da região. Pessoa manteve-se intendente de Ilhéus por muitos anos, sendo substituído por outro importante nome da política regional, o seu correligionário Misael da Silva Tavares. Vale lembrar que, àquela altura, Itabuna já se encontrava estabelecido como município independente de Ilhéus, cuja emancipação política se deu em 1910. O novo município era reduto dos pessoístas, tidos como representantes do grupo de Firmino Alves (considerado fundador da cidade).

O lugar hegemônico na política regional não bastava para os novos ricos. Como Mahony observou, a batalha política regional não se dissociava da batalha pelo lugar dessa nova elite na história da região cacaueira. Em 1914, por encomenda de Antônio Pessoa, Borges de Barros escreveu Memória sobre o município de Ilhéus. O livro faz um panorama dos tempos coloniais. Contudo, o eixo central da narrativa é a "civilização do cacau" e seus personagens principais: os pioneiros que enriqueceram com o trabalho na lavoura do cacau e tornaram-se prósperos, isto é, os novos ricos. Nas palavras de Mary Mahony: “Ao longo do livro, o progresso foi associado ao cacau e o cacau foi associado aos novos ricos e seus ancestrais". ${ }^{21}$

20 MAHONY, Mary Ann. Op., cit., p. 755.

21 Idem, p. 757. 
Na década seguinte, a conjuntura regional, impactada pelos acontecimentos internacionais, sobretudo econômicos, era outra. A crise econômica internacional dos anos 1920 se refletiu diretamente nos rumos da região sul da Bahia que, à época, era uma das principais exportadoras de cacau do mundo. Nesse processo, os abismos que separavam em batalhas violentas pessoístas e adamistas diminuem. Segundo Mahony, falou mais alto o interesse de classe diante da crise e as consequentes insatisfações dos trabalhadores rurais e grupos indígenas. ${ }^{22}$

Dessa forma, na nova geração, já não se fazia presente o separatismo adamista-pessoísta; ao menos, não como nos primeiros tempos da ascensão do cacau na região. $\mathrm{Na}$ nova fase, estabelecia-se um pacto de solidariedade de classe entre eles, particularmente visível nas alianças matrimoniais gestadas na região. Um exemplo desse pacto foi a ascensão política de Eusínio Lavigne, que guardava ancestralidade de ambos os grupos. Era descendente da tradicional família Sá, por um lado, e por outro, descendia de família imigrante, que chegou à região na segunda metade do século XIX. A aliança entre famílias tradicionais e os novos ricos culminou num programa de reforma relacionado ao cacau, que previa apaziguar as dificuldades socioeconômicas da região cacaueira. O programa de Lavigne para a região cacaueira

prometia estabelecer a ordem legal na região; promover a educação e a saúde nas zonas rurais e urbanas; melhorar a infra-estrutura, a pesquisa sobre o cacau e os programas de extensão agrícola; fazer lobby em favor do cacau baiano em capitais estrangeiras; estabelecer uma bolsa de valores para o

22 MAHONY, Mary Ann. Op., cit., p. 761. 
cacau com informações completas sobre as transações diárias no mercado estrangeiro; reformar o sistema de impostos; estabelecer cooperativas entre os produtores para negociar a compra e venda de cacau; e incentivar a industrialização do chocolate na própria região cacaueira. ${ }^{23}$

Na década de 1930, Eusínio Lavigne, quando intendente de Ilhéus e seguindo os passos de Antônio Pessoa, contratou João da Silva Campos "o mais importante historiador baiano da época, para escrever uma história de Ilhéus"24. Naquele contexto, a história a ser narrada abrigaria não mais os desagravos entre famílias tradicionais e novos ricos, mas uma história na qual, consensualmente, esses grupos apareceriam como os responsáveis pela expansão do cacau no sul da Bahia. A obra de Campos dissolvia a relevância das rivalidades políticas e evidenciava a escolha de Lavigne: uma história do cacau com base na cooperação e no trabalho de ambos os grupos. Como observa Mahony, o apelo à unidade se fazia importante em um contexto de crise econômica na região.

A crise econômica internacional da década de 1920 havia deixado, em 1930, os produtores de cacau quebrados ou muito endividados, e isso impactava diretamente na realidade dos trabalhadores rurais, que diante das dificuldades se mostravam insatisfeitos e começavam a se organizar contra os fazendeiros. Contudo, outro apelo estava incutido na nova narrativa histórica que o poder político da região se empenhava em construir. Tratava-se do papel de relevância dos "desbravadores" e produtores de cacau para a economia do Estado. O objetivo era legitimar, junto aos governos

23 MAHONY, Mary Ann. Op., cit., p. 762.

24 Idem, p. 764. 
estadual e federal, a obtenção de socorro financeiro aos cacauicultores. ${ }^{25}$

Na década de 1950, após a Segunda Guerra, os cacauicultores do sul da Bahia enfrentaram outra crise do cacau. Naquele momento, a narrativa da história da região do cacau e a história da atuação pioneira novamente vêm à tona. Entretanto, diferentemente do perfil das obras anteriores, tal discurso perpassava textos técnicos, acadêmicos e oficiais de vários estudiosos envolvidos em pesquisas sobre a região cacaueira na década de 1950. ${ }^{26}$

A economia cacaueira do sul da Bahia viveu movimentos cíclicos, ora com crescimento de vulto, ora com avassaladoras crises. Robson Dantas observa que, da década de 1930 até o final da década de 1960, “o Sul da Bahia viveu entre o desânimo e a expectativa de reversão da crise econômica do cacau" ${ }^{27}$. Dantas ressalta que o tema do desenvolvimento debatido no cenário nacional também estava presente não somente nos estudos econômicos e sociais acerca da economia cacaueira, mas também na literatura que envolvia o sul da Bahia. Em seu estudo, Dantas se preocupa em analisar o tema do desenvolvimento regional sob a ótica adoniana, bem como dialoga com a obra amadiana nas suas reflexões acerca do tema.

O tema do desenvolvimento da região cacaueira foi explorado na literatura de Jorge Amado, sobretudo em Terras do Sem Fim, publicado em 1942, e em São Jorge dos Ilhéus, publicado em 1944. Adonias Filho abordou o tema em Os Servos da Morte, de 1946; Memórias de Lázaro, publicado em 1952; Corpo Vivo, de 1962; Léguas da Promissão, de

25 MAHONY, Mary Ann. Op., cit., p. 765.

26 Idem, p. 773.

27 DANTAS, Robson Norberto. Op., cit., p. 145. 
1968; e As Velhas, este publicado em 1975. Jorge Amado retomou o tema em 1986, com Tocaia Grande, a face obscu$\mathrm{ra}^{28}$. Vale lembrar que tanto Jorge Amado quanto Adonias Filho faziam parte das famílias dos "novos ricos". Eles eram herdeiros dos denominados pioneiros da lavoura do cacau e colocavam-se na discussão sobre o desenvolvimento regional de modo muito próximo do discurso, que cunhava a ideia do pioneirismo da região cacaueira.

\subsection{A elaboração da acomodação do mito pioneiro regional para a história de Itabuna pelos intelectuais da década de 1960}

A narrativa de desenvolvimento da região sul da Bahia ligada ao cacau e à ideia dos pioneiros do cacau, engendrada desde as primeiras décadas do século $X X$ por intelectuais e estudiosos, foi apropriada pelos intelectuais itabunenses na década de 1960. Eles, por sua vez, elegeram os migrantes sergipanos como protagonistas da construção de uma memória coletiva oficial de Itabuna, que tinha como principal fim construir uma identidade sergipana para a cidade.

Na década de 1960, os itabunenses comemoravam o cinquentenário de emancipação política do município e, no decorrer daquela década, foram publicadas três importantes obras da memória de Itabuna: O Jequitibá da Taboca, Terras de Itabuna e Documentário Histórico Ilustrado de Itabuna. Os festejos comemorativos avivam certo sentimento de pertencimento, motivado por símbolos e representações identitárias. Desse modo, a escrita memorialista de Itabuna atuou

28 DANTAS, Robson Norberto. Op., cit., p. 146. 
como geradora de uma identidade sergipana que, por sua vez, seria atualizada na memória coletiva da cidade.

Denominamos de escrita memorialista uma memória coletiva oficial de Itabuna. Isso significa dizer que o discurso produzido e organizado pelos grupos hegemônicos da cidade estão presentes nos textos acadêmicos, na literatura, nas comemorações cívicas locais, no hino cívico da cidade, nas palestras escolares no contexto do aniversário do município, no teatro, nas aulas de história regional. Enfim, a memória heroica sergipana, daqueles que trabalharam e venceram, foi construída através das práticas discursivas e das representações, engendrando uma identidade sergipana que não é apenas coletiva. Ela também assume caráter oficial e é atualizada a cada ano pela evocação dos símbolos identitários nos espaços públicos e nos rituais oficiais. Levando-se em conta que "a memória é um elemento essencial do que se costuma chamar de identidade [...] é não somente uma conquista, é também um instrumento e um objeto de poder" ${ }^{29}$, entendemos que a narrativa sobre a história de Itabuna legitima o poder social dos intelectuais e dos políticos da década de 1960. Eles se apresentam no lugar e com o papel social de herdeiros dos precursores do desenvolvimento e do progresso de Itabuna. Iremos analisar mais adiante, neste capítulo, a discussão acerca da identidade como representação social.

Veremos, no terceiro capítulo, que, ao longo do século XIX, as relações entre colonos, escravos e índios eram muito próximas, como foi o caso do trabalho desenvolvido na estrada Ilhéus-Conquista por índios aldeados e escravos de fazendeiros locais. Contudo, na narrativa da

29 LE GOFF, Jacques. História e memória. 5. ed., Campinas: São Paulo, Editora da Unicamp, 2003, p.469-470. 
memória de Itabuna não se faz nenhuma alusão à presença de escravos africanos ou afrodescendentes trabalhando ao lado dos migrantes pobres e, quanto aos índios, são mencionados de forma indireta e sem nenhuma participação no processo de colonização da região. Eles são mencionados, mas o são na medida em que o memorialista faz referência aos tempos de frei Ludovico ${ }^{30}$. Com a presença dos migrantes, eles se tornaram obstáculos, foram empurrados para as matas e estavam fadados a desaparecer. Esse discurso perpassa todas as narrativas apresentadas. $\mathrm{O}$ inexorável desaparecimento do índio estava associado à "incompatibilidade" de sua presença com a civilização que estava sendo plantada naquelas paragens. Além do mais, a mata, aos poucos, desaparecia para dar lugar às inúmeras pequenas e médias roças, bem como às grandes fazendas de cacau. Ou seja, na perspectiva da escrita memorialista, o índio e a mata (de forma correlacionada) desapareceriam em nome do progresso da região.

O Jequitibá da Taboca, de Oscar Ribeiro Gonçalves, publicado em 1960, carrega uma peculiaridade muito interessante para se pensar a construção da memória. A obra é elaborada com base nos relatos de Manoel Fogueira, um dos ditos pioneiros. Nesse sentido, na construção do enredo de Gonçalves, temos a intermediação de dois

30 Frei Ludovico de Livorno foi o primeiro frade capuchinho italiano designado como diretor do aldeamento São Pedro de Alcântara ou aldeamento de Ferradas, em início do século XIX. Ele atuou junto aos indígenas aldeados por três décadas e se configurou como um personagem fundamental acerca dos direcionamentos do trabalho indígena na região sul da Bahia. Além das relações estabelecidas com o governo provincial, ele mantinha uma estreita ligação com os particulares da região, o que lhe denotava grande prestígio político e social. Ele caracterizou-se, ao longo de sua atuação na região, como um grande administrador do trabalho dos homens e mulheres aldeados, atuou não apenas junto aos índios de Ferradas, mas em grande parte da região sul da Bahia. Ver os capítulos II e III. 
narradores, a de Manoel Fogueira, que através do relato oral narra a história do marco zero, ou seja, das origens de Itabuna; e a intermediação de Oscar Ribeiro Gonçalves que, através da escrita, nos termos de Foucault, controla, seleciona, organiza e redistribui os acontecimentos e personagens para dar sentido ao seu enredo.

$\mathrm{Na}$ obra em questão, a narrativa da memória passa por dois filtros acerca da realidade que se deseja representar: o primeiro está presente no relato oral do primeiro narrador, Manoel Fogueira, e o segundo filtro é apresentado na construção discursiva, que tem a intenção de narrar a escrita da memória, empreendida por Ribeiro Gonçalves: "A documentação fornecida para que o presente volume se transformasse em realidade é obra de um sincero pioneiro, o Sr. Manoel Bonfim Fogueira, dono da maior tradição oral que se possa imaginar, acerca do município e da cidade de Itabuna" ${ }^{11}$. Essas são as palavras iniciais do prefaciador de O Jequitibá da Taboca, Plínio de Almeida, que era membro da Academia de Letras de Ilhéus. Plínio de Almeida segue ressaltando que:

O Sr. Oscar Ribeiro, recolhendo os informes fornecidos pelo Sr. Manoel Bonfim Fogueira, não pretendeu fazer obra acadêmica, ou romanesca, ou crônica onde apenas palpitam as palavras cantadas de uma poesia sem bases reais. [...] $\mathrm{O}$ material fornecido pelo Sr. Fogueira é do tipo que se pode batizar de 'primeira água', isto é, material muito bom pela fidelidade, pela verdade buscada e encontrada. ${ }^{32}$

31 GONÇALVES, Oscar Ribeiro. O jequitibá da Taboca. Itabuna: Oficinas Gráficas da Imprensa da Bahia, 1960, p. 15.

32 Idem, p. 16. 
Para o prefaciador e também para o autor do livro, a narrativa com base nos relatos de Fogueira dava ao seu enredo o caráter de verdade. Não era um trabalho de história, que envolvia a interpretação do passado nem tampouco romance ou crônica com base na imaginação. A obra trazia, em si, o próprio acontecimento, através do relato de quem o viveu e dava testemunho da realidade vivida. Nessa perspectiva, acerca do caráter que envolve a história e a memória, a representação do passado, Pesavento, evocando Paul Ricoeur, lembra que "à História, estaria negada a pequena alegria do reconhecimento preservado à Memória. Aquele que evoca, chega à identificação da lembrança com o acontecido, objeto da rememoração: foi ele, foi lá, foi então, foi assim!"’33

O primeiro capítulo de O Jequitibá da Taboca é dedicado a situar o leitor acerca das origens da cidade, para em seguida dar conta da realidade de progresso a que estaria destinada Itabuna, como herança da coragem dos seus pioneiros: os primeiros sergipanos ali chegados. São considerados como os primeiros sergipanos desembarcados em Ilhéus e fixados na região próxima a Ferradas: Felix Severino de Oliveira ou Felix Severino do Amor Divino e Manoel Constantino. Segundo Ribeiro Gonçalves, ambos vieram da Chapada dos İndios, Estado de Sergipe. $\mathrm{O}$ lugar onde teriam escolhido se estabelecer ficava às margens do Rio Cachoeira e a ele teriam dado o nome de Marimbeta e em seguida o batizariam de Tabocas. Assim Gonçalves relata a primeira cena da chegada dos sergipanos à região:

Sozinhos, neste dito lugar ermo, como teriam eles contemplado aquele cenário?

33 PESAVENTO, Sandra Jatahy. Op., cit., p. 55. 
A mata, os caboclos e as feras eram seus únicos vizinhos, mas além outeiros hirsutos, reduzindo-lhes o horizonte, mais ao lado, corre o rio Cachoeira no meio do qual se divisavam ilhas com matas incultas, árvores cujas copas se entrelaçavam numa selvatiqueza rude; um céu pincelado de nuvens escuras quase sempre a chover. No deslumbramento desse espetáculo irradiava a luz solar como a flor da esperança na vibração da mocidade. Pois bem: nesse ambiente solitário habitava Felix Severino do Amor Divino e seu companheiro, o crioulo Manoel Constantino. ${ }^{34}$

Gonçalves menciona, como parte de um único universo, a presença conjunta da mata, dos caboclos e das feras. Esse é o contexto, em sua narrativa, do primeiro contato dos migrantes sergipanos com a região. O que isso pode significar? O termo "caboclo", apresentado na obra, não parece aludir à mestiçagem luso-tupi ${ }^{35}$, pois, tal como empregado por Gonçalves, o caboclo está em um cenário selvagem e sugere muito mais o "índio selvagem", o botocudo, tão mais presente, naquela realidade regional, do que o mestiço. O caboclo aparece, portanto, representando o atraso, e mais como um obstáculo a ser vencido.

A ideia transmitida pela narrativa é a de lugar inculto, quase desabitado por gente, já que os índios são descritos ao lado da mata e das feras, portanto, uma extensão do mundo natural. A narrativa de Gonçalves faz emergir o discurso de que o índio das origens de Itabuna era "o

34 GONÇALVES, Oscar Ribeiro, Op., cit., p. 29.

35 MONTEIRO, John Manuel. Tupis, Tapuias e Historiadores: Estudos de História Indígena e do Indigenismo. Tese de livre docência. Campinas: Unicamp, 2001, p. 172. 
outro", que não fazia parte da história daquela parte do sul da Bahia. Mas, vale ressaltar que, àquela altura, no ano de 1844, descrito por Gonçalves como a data de chegada daqueles migrantes, a região era imensamente habitada. Ali viviam os grupos indígenas não aldeados, os aldeados, dentre eles, os de Ferradas, e ainda outros migrantes e estrangeiros que aos poucos já vinham habitando a região e tinham relações estreitas com os aldeamentos. O próprio Gonçalves reconhece que muitas das fazendas de cacau, construídas pelos novos habitantes e depois por outros conterrâneos, por ele relacionadas, já existiam anteriormente à Tabocas ${ }^{36}$. Contudo, era a história dos heróis sergipanos que deveria ser escrita e lembrada pela memória coletiva de Itabuna.

Em 2011, O Jequitibá da Taboca foi revisado, reeditado e publicado pela Editus, editora da Universidade Estadual de Santa Cruz (UESC), na ocasião do centenário de Itabuna, por Janete Ruiz de Macedo e João Cordeiro de Andrade, ambos integrantes do Centro de Documentação e Memória (CEDOC) da UESC. A professora Janete Macedo é uma importante pesquisadora e incentivadora da criação e manutenção dos arquivos municipais no sul da Bahia, trabalho realizado junto ao CEDOC. Ela explicita que o interesse em reeditar o raro livro O Jequitibá da Taboca se deu por dois objetivos: primeiro, atualizar as memórias de Manoel Fogueira para que todos, em especial os itabunenses, pudessem acessá-las; segundo, para tornar o livro disponível aos historiadores regionais, já que o considera uma fonte importante de estudo. ${ }^{37}$

36 GONÇALVES, Oscar Ribeiro, Op., cit., p. 28.

37 FOGUEIRA, Manoel Bonfim; GONÇALVES, Oscar Ribeiro. Ensaios históricos de Itabuna: O Jequitibá da Taboca, 1949-1960. 2. ed. Ilhéus: Editus, 2011, p. 27. 
Não obstante a importância de O Jequitibá da Taboca, entendemos que a reedição do livro, na ocasião do centenário da cidade, traz, em si, certo caráter de atualização da memória coletiva. A reedição dessa obra apresenta aos habitantes de Itabuna "um quadro de si mesma que certamente se desenrola no tempo, já que se trata de seu passado, mas de tal maneira que eles sempre se reconheçam nessas imagens sucessivas". ${ }^{38}$ Macedo conclui o texto de introdução ao livro da seguinte maneira:

\begin{abstract}
[...] espera-se que todos, em especial os itabunenses, jovens ou idosos, natos ou moradores, estudantes ou intelectuais, historiadores ou memorialistas, possam se apossar dessas memórias, e que haja a ambição de fidelidade ao passado, ameaçada quando as ideologias se intercalam entre a reivindicação de identidade e as expressões públicas da memória coletiva. ${ }^{39}$
\end{abstract}

A reedição da obra, apesar do caráter de atualização do mito pioneiro nela intrínseco, nos oportuniza estabelecer o diálogo entre a narrativa da memória e outros relatos documentais, por conseguinte, apontar a agência de outros sujeitos na narrativa da trajetória histórica de Itabuna; de modo particular, os índios de Ferradas, que foram invisibilizados na narrativa memorialista de 1960, objeto de estudo do trabalho em questão. Nesse sentido, ressaltamos, portanto, que as "ideologias" postas como "ameaças" à integridade do passado são muitas vezes reivindicações de outras identidades que desejam o alargamento da memória coletiva oficial de Itabuna.

38 HALBWACHS, Maurice. Op., cit., p. 109.

39 FOGUEIRA, Manoel Bonfim; GONÇALVES, Oscar Ribeiro. Op., cit., p. 29. 
Também é de 1960 a publicação de Terras de Itabuna, do jornalista Carlos Pereira Filho. A matéria publicada no Diário de Itabuna explicita o tom positivo com o qual a obra de Pereira Filho foi recebida entre os jornalistas e demais representantes do poder político e econômico da lavoura do cacau, de quem Pereira Filho era denominado de procurador:

[...] vimos cumprimentá-lo, hoje [...] em nosso nome [...] como ainda em nome da lavoura cacaueira, de quem se constitui um dos mais ardorosos advogados, não perdendo tempo, não tendo cansaços, toda vez que há necessidade de uma ação urgente, enérgica, como procurador das associações que representam os interesses da lavoura cacaueira. ${ }^{40}$

Em seu livro, Pereira Filho pontua o papel progressista da formação de Itabuna que, segundo ele, era consonante à própria trajetória de construção do Brasil. $\mathrm{O}$ autor faz um panorama da economia brasileira, que, em sua perspectiva, correspondia ao ciclo do açúcar, do ouro, do café e do cacau. Segundo Pereira Filho, naquela década (1960), ainda se vivia o tempo do café, do cacau e do gado, mas a economia de Itabuna, assim como a do Brasil, caminhava de forma acelerada para a industrialização ${ }^{41}$. Podemos refletir sobre dois aspectos da escrita deste autor: primeiro, não é demais lembrar que, na década de 1960, a região tentava se erguer de mais uma crise econômica do cacau. O momento parecia oportuno para lembrar o papel dos antepassados, considerados os responsáveis pelo

40 CEDOC; Diário de Itabuna, 14 de maio de 1960, Ano III, nº 698, p. 1.

41 PEREIRA FILHO, Carlos. Terras de Itabuna. Rio de Janeiro: Elos, 1960, p. 13-14. 
emergir grandioso de Itabuna. Mas ao salientar o papel da indústria como propulsora da economia regional, intrinsecamente está presente, no discurso do autor, a ideia de um caminho disponível para o progresso da região para além da economia cacaueira. A obra de Pereira Filho apresenta uma saída para a crise vivida pelas elites de Itabuna, que deveriam pensar na industrialização regional para minimizar os efeitos da crise do cacau.

O segundo aspecto diz respeito à relação pioneirismo e progresso, estabelecida pelo autor, na referida obra, e à evocação da figura do bandeirante paulista, associando-a ao do pioneiro itabunense. Nas palavras de Pereira Filho:

[...] o que é Itabuna, representada pela sua força social, econômica e política, todos sabem e todos conhecem pela posição que ocupa na colocação dos municípios brasileiros. Aos itabunenses poderíamos aplicar aqueles magníficos versos de Olavo Bilac, endereçados ao desbravador bandeirante: "cada passada tua era um caminho aberto, cada pouso mudado, uma nova conquista, teu pé, como de um deus, fecundava o deserto". ${ }^{42}$

Em estudo sobre os pioneiros da região cacaueira do sul da Bahia, com base na figura dos novos ricos de Ilhéus, que estabeleciam um contraponto com a aristocracia escravista açucareira, Mary Mahony ressalta que "a ênfase sobre desbravadores e produtores progressistas fez com que os cacauicultores e seus ancestrais parecessem mais com os heroicos bandeirantes e produtores progressistas de São Paulo do que com os abatidos aristocratas

42 PEREIRA FILHO, Carlos. Op., cit., p. 14. 
da indústria açucareira da Bahia" ${ }^{43}$. Nesse sentido, observamos que assim como os intelectuais da região estavam envolvidos em escrever uma história heroica para Ilhéus, nas décadas de 1920 e 1930, com base na figura dos progressistas novos ricos, também em Itabuna, na década de 1960, a elite política e intelectual empreendia esforços na escrituração de uma narrativa do pioneirismo progressista sergipano, no intuito de construir uma história vitoriosa para a cidade de Itabuna. Pereira Filho conclui: "Itabuna deve seu progresso e sua prosperidade aos seus próprios desbravadores". ${ }^{44}$

No rol dos "desbravadores" de Itabuna, comparados aos paulistas por Pereira Filho, estão as figuras de Firmino Alves, Militão Oliveira, Henrique Alves e Gileno Amado como "homens que descobriram e ajudaram a construir o município". Por conseguinte, todo itabunense deveria conhecê-los ${ }^{45}$. Os nomes citados por Pereira Filho representam os novos ricos de Itabuna. Eram, em sua maioria, correligionários de Antônio Pessoa e Misael Tavares, coronéis do cacau, que norteavam a política e a economia de Itabuna, em início do século XX, de quem descendia a elite política e intelectual da década de 1960, preocupada em escrever tal história.

Anteriormente a Terras de Itabuna, Pereira Filho escreveu Ilhéus, terra do cacau, analisado por Mary Mahony. Nota-se entre essas obras uma diferença significativa: de acordo com Mahony, na narrativa histórica de Ilhéus, o jornalista Carlos Pereira Filho é um opositor à ideia posta pela narrativa tradicional vigente à época, que contava a

43 MAHONY, Mary Ann. Op., cit., p. 765.

44 PEREIRA FILHO, Carlos. Op., cit., p. 16.

45 Idem, p. 20. 
história da lavoura cacaueira ligada ao trabalho dos pioneiros, ocultando, em contrapartida a utilização da mão de obra escrava. Em Ilhéus, terra do cacau, afirmou que a lavoura cacaueira teria nascido ao lado dos engenhos de açúcar ${ }^{46}$ da comarca, fazendo menção à presença do trabalho escravo na implantação de ambas as lavouras. Já em Terras de Itabuna, o autor reverencia o papel dos sergipanos como os precursores de uma cidade notável, representante do progresso no Estado da Bahia. Dessa forma, entendemos que o discurso narrativo de Terras de Itabuna representa um esforço de apresentar a cidade separada do passado de Ilhéus que, segundo Pereira Filho, teria edificado seus cacauais nas práticas arcaicas da antiga aristocracia. Nessa perspectiva, ao contrário de Ilhéus, onde o autor associou a história dos pioneiros do cacau à história da aristocracia escravocrata, Itabuna teria nascido, tão somente, pelo suor e trabalho dos seus pioneiros, os sergipanos.

Em Documentário Histórico Ilustrado de Itabuna, de 1968, José Dantas de Andrade escreve de forma épica, afirmando que "Itabuna foi uma índia, que Félix Severino encontrou no mato e entregou a seu sobrinho José Firmino Alves, o qual lhe soube dar boa criação, educação, instrução e beleza" ${ }^{\prime 4}$. A referida citação parece ser um exemplo pertinente do caráter progressista que envolvia a narrativa da memória de Itabuna. Novamente a narrativa da memória faz alusão à presença indígena nas origens de Itabuna, mas o faz de forma efêmera e transitória, pois a índia que era Itabuna, encontrada por Félix Severino de Oliveira, o sergipano, deixaria o estado selvagem para assumir "os

46 MAHONY, Mary Ann. Op., cit., p. 778.

47 ANDRADE, José Dantas de. Documentário Histórico Ilustrado de Itabuna. Itabuna: Gráfica Editora Itabuna, 1968, p. 18. 
modos da sociedade" por intermédio do seu fundador, Firmino Alves, também sergipano.

De acordo com os registros memorialistas, após a chegada e o estabelecimento de Félix Severino do Amor Divino à região, ele, aos poucos, levou seus familiares para lá também, dentre os quais o sobrinho José Firmino Alves que, por sua vez, se tornou uma das principais figuras políticas da região, aclamado como fundador de Itabuna. Firmino Alves representa, na memória coletiva oficial de Itabuna, o ícone do legado pioneiro da cidade. A identidade sergipana que se desejava criar estava ligada à figura de empreendedorismo e trabalho de Firmino Alves; dessa forma, estava sendo forjada uma identidade positiva, à qual os itabunenses deveriam sentir-se pertencentes, em meio aos desânimos e expectativas de restabelecimento da economia regional.

José Firmino Alves de Souza Freire, neto de Firmino Alves, também se fez presente no processo da escrita da história de Itabuna, durante as comemorações do seu cinquentenário. Seu discurso evoca as comemorações em homenagem ao centenário de nascimento de Firmino Alves, no contexto do cinquentenário de Itabuna, de forma que a história de Itabuna, e a dele, seu fundador, se intercruzam na memória da cidade. Segundo Freire, "ao completar 100 anos de seu nascimento [...], as autoridades e o povo de Itabuna, em colaboração com as autoridades dos Estados da Bahia e Sergipe e de vários municípios, lhe prestaram significativa homenagem, através de festas jamais assistidas nesta cidade" ${ }^{\prime 4}$. Portanto, na década anterior ao cinquentenário de Itabuna, foram empreendidos esforços,

48 FREIRE, José Alves de Souza. Firmino Alves: Fundador de Itabuna. Itabuna: Edições ITAGRAF, 1963, p. 22. 
por parte do governo municipal, bem como dos municípios vizinhos do governo dos estados da Bahia e de Sergipe, para os festejos do centenário de Firmino Alves.

Na perspectiva de Sandra Pesavento, "a identidade é uma construção simbólica de sentido, que organiza um sistema compreensivo a partir da ideia de pertencimento. A identidade é uma construção imaginária que produz a coesão social" ${ }^{49}$. Portanto, a identidade sergipana foi engendrada na década de 1960 através de um jogo simbólico e de representação no qual os sergipanos foram evocados, em detrimento de outros tantos atores presentes na história das origens da cidade que, por sua vez, foram invisibilizados pela narrativa da memória. $\mathrm{O}$ poder de tal construção simbólica reside no fato de que ela mantém uma memória coletiva coesa. Ainda que haja espaço para outras memórias coletivas na sociedade itabunense, é importante notar que existe uma memória coletiva oficial, cultuada pela prefeitura, por exemplo, que legitima o pioneirismo e a centralidade dos sergipanos.

A memória coletiva estava sendo engendrada e sistematizada através da narrativa memorialista, mas também,por meio de outros recursos discursivos, como era o caso do jornal Diário de Itabuna, no qual circulava um ponto de vista da história associado aos interesses da elite política e intelectual da região, como já demonstramos no início do texto. Uma matéria de página inteira do jornal, no mês no aniversário da cidade, sintetiza na figura de Firmino Alves a relação entre o pioneiro e a cidade do progresso, bem como, mais uma vez, imbrica a história de origem à memória sergipana:

49 PESAVENTO, Sandra Jatahy. Op., cit., p. 89. 
A propósito das festas do cinquentenário de Itabuna, destas colunas lembramos de uma feita à Comissão dos festejos a necessidade de um convite oficial ao Governo e ao poder Legislativo Sergipano. Nos reportamos ao brilho dado às festas do centenário do nascimento de Firmino Alves, fundador da cidade, quando Sergipe mandou uma embaixada composta de deputados e jornalistas. Com ela veio também a bandeira sergipana pertencente ao Instituto Histórico de Aracajú, a qual, por solicitação de Itabuna foi concedida para as festividades por gentileza de seu Presidente e fez aqui parte no desfile, carregada por elementos representativos da colônia sergipana. Não é demais pois, lembrarmos mais uma vez a conveniência do convite, porque nessa festa Sergipe tem o seu quinhão muito importante. O sergipano foi um desbravador deste grande Município que é hoje Itabuna, orgulho da Bahia. Participou das lutas e canseiras, sem o que não estaríamos hoje, orgulhosos e satisfeitos comemorando uma data que nos é rara [...], com o exemplo dado pela bravura e destemor dos pioneiros que vieram do Estado vizinho trabalhar para nossa grandeza. ${ }^{50}$

Na matéria citada, o colunista remete os festejos do cinquentenário da cidade de Itabuna ao festejo do centenário de nascimento de Firmino Alves, ocorrido em 1953. Ressalta a presença oficial do Estado de Sergipe nas comemorações daquela ocasião, e evidencia a necessidade de remeter ao governo sergipano um convite oficial, para que Sergipe participasse do cinquentenário de Itabuna.

50 CEDOC; Diário de Itabuna, Sexta-feira, $1^{\circ}$ de julho de 1960, Ano III, $\mathrm{n}^{\mathrm{o}} 730$, p. 1 
Portanto, era na consolidação da identidade pioneira e em sua trajetória histórica que residiam a eficácia da memória coletiva da cidade, haja vista que "a batalha pelo controle político da região sempre esteve intimamente ligada à luta pelo controle da história". ${ }^{51}$

Desde a década de 1930, os trabalhadores rurais se mostravam insatisfeitos, e os ânimos se exaltavam, tanto no campo quanto na cidade, em virtude das dificuldades econômicas e demandas sociais não atendidas. Depois de sucessivas crises externas e internas pelas quais passou a economia regional baseada na monocultura do cacau, se estabeleceu um alto índice de desemprego na região sul da Bahia. Naquele contexto, os trabalhadores voltaram a se organizar sindicalmente, sob a liderança do Partido Comunista Brasileiro (PCB). Em 1957, o Ministério do Trabalho brasileiro reconheceu oficialmente a União dos Trabalhadores Rurais de Itabuna e Ilhéus. Vale observar que aquela era a única organização rural da Bahia a receber tal reconhecimento ${ }^{52}$. Como desdobramento desses acontecimentos, no início da década de 1960, as ligas camponesas estavam ativamente reivindicando uma reforma agrária radical". ${ }^{53}$

Foi no bojo das dificuldades econômicas e sociais nas quais estava imersa a região cacaueira que a elite política e intelectual de Itabuna se ocupou em escrever a história dos que trabalharam e venceram, de quem eles haviam herdado as suas riquezas. No contexto de insatisfação dos trabalhadores rurais era pertinente contar a história de origem pela perspectiva do homem simples da roça, mi-

51 MAHONY, Mary Ann. Op., cit., p. 739.

52 Idem, p. 774.

53 Idem, ibidem. 
grante pobre que, de forma destemida, derrubou a mata, plantou o cacau, trabalhou muito e venceu. Nas palavras de Pereira Filho:

Por muitos anos esses homens trabalharam anonimamente, humildemente, bravamente, derrubando matas, fazendo roças, plantando cacau, acumulando riquezas. Verdadeiros heróis das selvas, isolados do mundo, da civilização, adoeciam e morriam sem remédio, sem conforto, sem assistência $[\ldots]$, a riqueza daquela terra $[. .$.$] , se havia$ construído, com sacrifício, com martírio de uma geração, com trabalho audacioso ${ }^{54}$.

Contudo, a escolha por escrever a narrativa histórica de Itabuna pelo viés do pioneirismo sergipano demandava invisibilizar outros atores daquele processo. Nessa empreitada, os índios aldeados de Ferradas, que atuaram indireta e diretamente na lavoura do cacau, possibilitaram o acesso de colonos à região, bem como empregaram a sua mão de obra nas roças de cacau, durante o século XIX, foram propositalmente invisibilizados na história que se desejava criar. Nesse sentido, vale citar novamente Pesavento, para quem, na construção da memória, o esquecer está tão presente quanto o lembrar ${ }^{55}$. Também Paul Ricoeur frisa que "o esquecimento pode estar tão estreitamente confundido com a memória que pode ser considerado como uma de suas condições". ${ }^{56}$

54 PEREIRA FILHO, Carlos. Op., cit., p. 30-31.

55 PESAVENTO, Sandra Jatahy. Op., cit., p. 95.

56 RICOEUR, Paul. A memória, a história, o esquecimento. Campinas, São Paulo: Editora da Unicamp, 2007, p. 435. 


\subsection{O jogo de lembrar e esquecer: o afastamento de Ferradas na escrita da memória de Itabuna}

Paul Ricoeur, em A memória, a história, o esquecimento, tece algumas importantes observações acerca da relação entre memória e esquecimento, que são norteadoras para as reflexões propostas neste tópico do capítulo. Desse modo, elencaremos algumas de suas contribuições a partir de duas categorias da memória que ele denomina de "memória impedida" e "memória manipulada".

Paul Ricoeur trabalha com a categoria de "memória impedida" para tratar do esquecimento da memória. Para tanto, ele estabelece um diálogo direto com a psicanálise. Ressalta a tese freudiana de que "o paciente repete, ao invés de se lembrar. Ao invés de: a repetição vale esquecimento" ${ }^{\prime 57}$. Segundo Ricoeur, a primeira lição dada pelos psicanalistas é a de que "o trauma permanece mesmo quando inacessível, indisponível. No seu lugar surgem fenômenos de substituição, sintomas que mascaram o retorno do recalcado de modos diversos ${ }^{\prime 58}$.

Para Ricoeur, "o esquecimento de impressões e de acontecimentos vivenciados [...] e o esquecimento de projetos que equivalem à omissão, à negligência seletiva, revelam um lado ardiloso do inconsciente colocado em postura defensiva"; ;9 ele ressalta que as manifestações individuais e coletivas do esquecimento estão misturadas de forma inextricável ${ }^{60}$, e pontua que é na memória coletiva que o esquecimento produz os efeitos mais nocivos.

57 RICOEUR, Paul. Op., cit., p. 452.

58 Idem, p. 453.

59 Idem, p. 454.

60 Idem, p. 451. 
Nas palavras do autor, "esquecimento, lembranças encobridoras, atos falhos assumem, na memória coletiva, proporções gigantescas, que apenas a história e, mais precisamente, a história da memória é capaz de trazer à luz" ${ }^{61}$

A segunda categoria da memória trabalhada por Ricoeur é a da "memória manipulada". Segundo ele, a manipulação da memória se dá por via ideológica, pela mediação da narrativa ${ }^{62}$. O autor ressalta que é impossível lembrar tudo, assim como é impossível narrar tudo. Aqui, esquecimento e narrativa da memória caminham juntos. E em se tratando da ideologização da memória, Ricoeur frisa ser ela possibilitada pela variação do trabalho da configuração narrativa, ou seja, pelo modo como o narrador irá compor ou delinear a sua narrativa, pois "pode-se sempre narrar de outro modo, suprimindo, deslocando ênfases, refigurando diferentemente os protagonistas da ação assim como os contornos dela". ${ }^{63}$ É nesse jogo do esquecimento da memória que tentaremos identificar os meandros da invisibilização dos índios de Ferradas. À medida que se opera, na narrativa, o afastamento, o silenciamento do núcleo indígena (Ferradas) da história, os índios, sucessivamente, são afastados junto com a aldeia.

A construção da memória pioneira de Ilhéus, estudada por Mahony, tinha por finalidade esconder o passado escravocrata e negar a atuação da mão de obra escrava na lavoura do cacau. A escrita da memória de Itabuna, embora estivesse em sintonia com os aspectos mais gerais da escrita da memória regional, guardava uma peculiaridade. Diferentemente da de Ilhéus quatrocentona, na narrativa

61 RICOEUR, Paul. Op., cit., p. 455.

62 Idem, Ibidem.

63 Ibidem. 
memorialista da década de 1960, a jovem Itabuna se sentia livre do fardo de um passado escravocrata, muito embora a sua lavoura de cacau também tenha sido construída com braços escravos e mão de obra compulsória indígena, como veremos, mais adiante, neste livro.

A particularidade presente na narrativa de Itabuna com relação à narrativa de Ilhéus residia no esforço empreendido pela obra memorialista itabunense, para construir uma ideia da ausência indígena no delineamento da história de origem de Itabuna. Para Sandra Pesavento, "as identidades podem dar conta dos múltiplos recortes sociais, sendo étnicas, raciais, religiosas, etárias, de gênero, de posição social, de classe ou de renda, ou ainda profissionais" ${ }^{\prime 64}$. Segundo essa perspectiva, a narrativa memorialista de Itabuna se pautou, dentre outros, num recorte de posição social, tendo em vista que as narrativas apresentadas estão voltadas a estabelecer o lugar social dos sergipanos e de seus descendentes na história de Itabuna e, em consequência disso, a escrita da memória está marcada por um viés de exclusão étnica, pois para que a identidade sergipana fosse construída era necessário que os índios fossem invisibilizados.

Lembrando as reflexões de Ricoeur, podemos inferir que a narrativa memorialista de Itabuna, através da manipulação da memória, suprime os índios da narrativa histórica da cidade, enfatiza a presença e atuação pioneira, para assim, dar os contornos desejados pela história que se quer narrar. Também Sandra Pesavento observa que, na construção da memória, "as pessoas são ensinadas a lembrar e esquecer, fazendo com que determinados acontecimentos não sejam considerados importantes ou mesmo

64 PESAVENTO, Sandra Jatahy. Op., cit., p. 91. 
que não tenham acontecido"65; nesse jogo de lembrar e esquecer, o objetivo é a construção de uma memória coletiva coesa que, por sua vez, legitime a identidade sergipana de Itabuna como sendo a memória oficial da cidade.

A elite de Itabuna era, em grande parte descendente de negros e índios, como era o caso de Firmino Alves: um "pardo de Sergipe, que se estabeleceu na região em meados do século XIX e se casou com uma mulher de ascendência indígena". ${ }^{66}$ Contudo, construiu uma memória da qual eles são excluídos, fazendo emergir apenas o passado sergipano. Foi construído para Itabuna um histórico étnico de negação da presença indígena. Eles estavam lá, num passado remoto, e desapareceram à medida que entraram em cena os sergipanos. A narrativa da memória de Itabuna, de 1960, estava toda ela norteada por um discurso progressista, que colocava Itabuna num patamar elevado na composição dos municípios da Bahia. Essa narrativa, em contrapartida, engendrava a ideia da presença indígena em Ferradas em um passado distante, porque naquele contexto, o da década de 1960, a imagem que se desejava criar para a origem da cidade, de civilização e progresso, não comportava o reconhecimento da presença indígena em suas origens, pois os índios representavam a ausência de civilização e obstáculo ao progresso da região. Esses são os argumentos que tentaremos tecer, a partir daqui, acerca do afastamento de Ferradas e dos índios, sobre a memória coletiva oficial de Itabuna.

A leitura feita sobre as populações indígenas do sul da Bahia na escrita memorialista era extremamente pejorativa. Os índios eram descritos como os selvagens

65 PESAVENTO, Sandra Jatahy. Op., cit., p. 96.

66 MAHONY, Mary Ann. Op., cit., p. 746. 
que, percebendo a inutilidade de suas flechas diante das armas de fogo dos colonizadores, se aprofundavam nas matas. É dessa maneira, por exemplo, que José Dantas de Andrade narra a situação do contato entre índios e não índios naquela parte do sul da Bahia. Ele assevera que nos encontros "entre índios e desbravadores, a vitória ficava sempre com os segundos, obrigando a que os silvícolas, compreendendo a inutilidade de suas flechas contra as espingardas, bacamartes e mosquetões, fossem se aprofundando cada vez mais nas matas, cedendo terreno ao avanço dos brancos" ${ }^{67}$

Assim como na escrita da memória, também na literatura regional encontramos a descrição pejorativa com relação às populações indígenas do sul da Bahia. Nessa perspectiva, dentre outras obras, se destaca Corpo Vivo, de Adonias Filho, publicado naquela mesma, década de 1960. Adonias Filho era um importante romancista da região e certamente tinha os intelectuais de Itabuna como seus leitores.

Corpo Vivo, de 1962, trata da violência e expropriação das terras dos pequenos agricultores por parte dos grandes produtores de cacau. $\mathrm{O}$ enredo narra a vingança de Cajango, um mestiço que, após o assassinato da família, é criado pelo tio índio, Inurí, "que lhe incutiu o ódio e a vingança e o transformou num animal selvagem, impedindo que ele se tornasse homem" ${ }^{\prime 68}$. Na perspectiva de Adonias Filho, Inurí, o índio representante das populações indígenas do sul da Bahia, era caracterizado como fera, cuja estratégia de reação aos colonizadores era a vingança. A personagem denota o caráter negativo empregado pelo autor acerca dos índios habitantes da região. Era dessa ideia que

67 ANDRADE, José Dantas de. Op., cit., p. 21.

68 DANTAS, Robson Norberto. Op., cit., p. 149. 
compartilhavam os memorialistas que se envolveram em escrever a história de Itabuna, naquela mesma ocasião.

A narrativa memorialista de Itabuna, em lugar de engendrar um passado "selvagem" e, portanto, fracassado, objetivava construir uma ideia progressista acerca da atuação dos sergipanos de Tabocas. Para tanto, estabeleceu um distanciamento entre Tabocas e Ferradas na memória coletiva oficial de Itabuna. Ferradas representava a presença e atuação indígena, e isso era uma parte da história que se desejava esquecer ou, pelo menos, deveria ser guardada num lugar distante, nessa memória oficial.

Em Terras de Itabuna, Pereira Filho observa que "em cinquenta anos o que realizou o povo itabunense impressiona e maravilha [...]. Cidade que tem uma elite intelectual, que tem bons jornais, estações de rádios, bons colégios" $^{\prime 69}$, ou seja, era a cidade pródiga e civilizada, na qual não cabia a primitiva Ferradas, lugar de índios. Pereira Filho ressalta que "muito distante está a época em que, em Ferradas, Frei Ludovico de Liorne prestava socorro a alguns índios desamparados ${ }^{\prime 70}$. Na sua narrativa de decadência de Ferradas, ele continua:

Como andava o arraial em decadência! Ferradas, que em 1856 possuía cacau, café, que se fundou antes de Tabocas e que teve visitas ilustres, como a de Martius, de Maximiliano e daquele Guilherme Frederico, Barão Von Den Bussche, estava parada... Parou como vila, acabaria como simples arraial ou mesmo como uma rua comprida, acompanhando o rio Cachoeira ${ }^{71}$.

69 PEREIRA FILHO, Carlos. Op., cit., p. 15

70 Idem, ibidem.

71 Idem, p. 27. 
Enquanto Tabocas era apontada como o protótipo de riqueza, Ferradas assinava sua sentença de morte com o tempo, pois a ela estavam fadados o fracasso, a falência. Era a Ferradas de frei Ludovico e dos seus índios aldeados: "Ferradas teve dias gloriosos [...]. Mas tudo passou. Frei Ludovico, velho e enfermo, foi morrer no seu convento, em Salvador".$^{72}$ Com sua morte, parece também que morre Ferradas, e os índios desaparecem, para dar lugar ao progresso da região, pois, ressaltava-se que "enquanto os índios recuavam para as matas, levas e levas de desbravadores se apoderavam das terras boas para o cacau". ${ }^{73}$

Portanto, a narrativa de origem, gestada na década de 1960, não associou à imagem de Itabuna um passado indígena. Ao contrário disso, ao forjar a imagem do pioneiro sergipano, a escrita memorialista escamoteia a importância estratégica de Ferradas e com isso invisibiliza os índios na memória coletiva oficial.

Esse era um distanciamento historicamente construído, que demarcava diferenças étnicas, culturais, sociais e políticas entre o lugar dos índios e o lugar dos outros. A memória coletiva oficial de Itabuna atinge uma coesão quando faz várias exclusões, em particular a dos índios, e pela sua força mitológica de atualização e formalização dos símbolos e representação identitária, com se verá a seguir.

72 PEREIRA FILHO, Carlos. Op., cit., p. 26.

73 Idem, ibidem. 


\subsection{Algumas reflexões acerca da atualização do mito pioneiro}

Em estudo sobre os símbolos de identidade social do centro da cidade de Itabuna, a professora Lurdes Bertol Rocha aponta as principais edificações públicas que, segundo ela, compõem a memória da cidade. Entendemos, no entanto, que elas não compõem naturalmente a memória, mas são símbolos da construção da memória coletiva, geradora do mito pioneiro. Realmente, algumas dessas edificações se constituem de importantes símbolos da presença "pioneira" na memória coletiva oficial da cidade.

Dentre os símbolos constitutivos da identidade sergipana nos espaços do centro da cidade de Itabuna, destacamos: O Edifício Comendador Firmino Alves, centro de decisões com relação à lavoura do cacau nas décadas de 1950 e 1960; O Museu Casa Verde, que Rocha destaca por sua importância cultural para Itabuna, visto que retrataria a vida do coronelismo, "onde foram reconstruídos os costumes e a época de uma das fases mais importantes da história regional". ${ }^{74} \mathrm{O}$ então museu Casa Verde foi, outrora, residência do coronel Henrique Alves; Praça Santo Antônio, local em que, no ano de 1944, foi inaugurado, no centro da praça, um monumento em homenagem a Firmino Alves. Além desses espaços, dentre tantos pontuados pela autora, poderíamos apontar, ainda, inúmeras ruas, escolas e outros espaços públicos que lembram os migrantes de Sergipe, que ali chegaram a partir da segunda metade do século XIX e seus descendentes.

Os símbolos edificados no centro de Itabuna explicitam o exercício da memória, no sentido de fazer lembrar o lugar

74 ROCHA, Lurdes Bertol. O centro da cidade de Itabuna: trajetórias, signos e significados. Ilhéus: Editus, 2003, p. 118. 
das elites da cidade com seus nomes e feitos. Pelo exercício da representação identitária, a versão das elites da cidade é apresentada à memória coletiva como a própria história local. Concomitantemente, essas versões são repetidas, quando não pela preservação de monumentos, pela narrativa literária ou, ainda, por trabalhos acadêmicos que estudam a história regional. A exemplo disso, Rocha destacou que

\begin{abstract}
apenas $1,8 \%$ dos entrevistados [...] citam o monumento localizado na Praça Santo Antônio [...] como signos que lhes digam alguma coisa [...]. Isto parece significar o total desconhecimento da história da cidade e, naturalmente, o não compromisso em relação à manutenção de sua memória ${ }^{75}$.
\end{abstract}

A observação da autora, de que o desconhecimento dos monumentos existentes no centro da cidade, por parte da maioria dos seus moradores, significa descompromisso com a manutenção da memória, merece uma pergunta, ainda que óbvia: A que memória se refere? Ela se refere a uma memória específica; a memória oficial dos sergipanos, especialmente a figura de Firmino Alves, como podemos notar na referência feita a alguns monumentos do centro de Itabuna, exemplificados acima, ligados à figura de Firmino Alves e a seus pares. Dessa forma, o trabalho de Rocha reflete a permanência da versão das elites da década de 1960, em trabalhos mais recentes, acerca da trajetória histórica de Itabuna.

Os diversos trabalhos memorialistas, e, também, os acadêmicos, técnicos e literários publicados ao longo do século $X X$, tinham a preocupação de engendrar uma história para a região do cacau, e funcionaram, e, em

75 Idem, p. 125. 
certa medida, ainda funcionam como controle da história regional, enquadrando-a como a história dos pioneiros do cacau. Aqui, vale citar Mahony. Ela aponta que "o poder da mitologia da história do cacau reside no fato de que ela não é imposta, pois se apresenta espontaneamente [...] nos vários estudos [...] publicados e repetidos indefinidamente $[\ldots .$.$] ao longo de todo o século X X^{\prime \prime 76}$.

Também a obra do memorialista Adelino Kfoury Silveira, publicada em 2002 e recebida com entusiasmo pela "sociedade itabunense", se constitui em bom exemplo de atualização da memória oficial de Itabuna. O autor de Itabuna, minha terra atuou como membro do Instituto Geográfico e Histórico da Bahia, foi sócio titular da Associação Brasileira de Relações Públicas e sócio efetivo da Associação Baiana de Imprensa. Vale ressaltar que foi proprietário de um considerável acervo histórico e atuante sobre a vida pública de Itabuna. Falecido recentemente, ele era reconhecido social e politicamente como importante guardião da história da cidade.

Em Itabuna, minha terra, Kfoury critica a visão do coronel do cacau posta pelas literaturas amadiana e adoniana, acusadas de ter construído um estereótipo de ambição e desonestidade para os homens pobres enriquecidos com o cacau. Ele ressalta a necessidade de não se perder de vista que, antes de considerar o mandonismo, com base no poder econômico e político dos coronéis da região, não se podia esquecer que eles foram os pioneiros, trabalharam e, portanto, naturalmente construíram o lugar econômico, político e social que ocupavam. Contudo, o mais interessante é notar que o discurso de Kfoury tenta retirar o peso negativo, que desgasta a figura dos coronéis e enaltece a

76 MAHONY, Mary Ann. Op., cit., p. 789. 
crença de que, de fato, eles representavam o passado árduo de trabalho e construção da riqueza regional:

Qual seria, pois, a figura real do coronel do cacau? Achamos ser de justiça entender que ele foi acima de tudo um desbravador [...]. Só mesmo a ação do tempo, o correr dos anos, fez com que esse exemplo de tenacidade gerasse o respeito e a obediência dos habitantes da região. Daí, num processo natural, foram chegando às suas mãos a riqueza e a força política. ${ }^{77}$

O autor segue a narrativa estabelecendo um distanciamento entre os "novos ricos" e a antiga aristocracia dos engenhos, ao dizer que havia diferenças "a se considerar e estabelecer entre o nosso coronel e os senhores de engenho, é que ele vivia em casebres no âmago da floresta, dormindo em rede ou cama de esteira".${ }^{78}$ Dessa maneira, Kfoury reforça o discurso dos memorialistas da década de 1960, de que a riqueza da elite itabunense era herança dos legítimos construtores de Itabuna.

Para Sandra Pesavento, "a elaboração dos mitos de origens vai ao encontro das identidades nacionais, compondo conjuntos de referência para as raízes de um po-

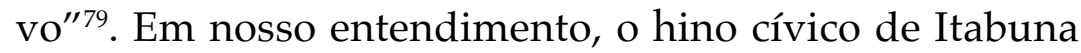
foi evocado como um importante símbolo constituidor dessas identidades. Portanto, além da atualização do mito pioneiro, na narrativa memorialista, a emergência de um hino oficial para Itabuna no contexto do centenário compõe, de forma eficiente, a naturalização da versão

77 SILVEIRA, Adelino Kfoury. Itabuna, minha terra. Itabuna: Gráfica Santa Helena, 2002, p. 14-15.

78 Idem, p. 15.

79 PESAVENTO, Sandra Jatahy. Op., cit., p. 91. 
discursiva construída para o cinquentenário da cidade, em 1960.

Em 2010, às vésperas de comemorar os cem anos de Itabuna, a Fundação Itabunense de Cultura e Cidadania (FICC) lançou o concurso para eleição do hino oficial de Itabuna, já que o hino conhecido como o hino da cidade, até então, não seria oficial por não possuir nenhum registro de sua oficialização junto à Câmara Municipal da cidade. O concurso provocou verdadeiro rebuliço: os "guardiães da memória da cidade" consideraram a atitude da FICC um ultraje e descaso à história de Itabuna. Não foram poucas as manifestações de protesto em rádios, blogs e sites que circulavam na cidade. No entanto, em detrimento das reivindicações empreendidas, o concurso foi realizado e eleito o novo hino de Itabuna, a ser cantado nas cerimônias formais e distribuído pela Secretaria de Educação para as escolas municipais, no intuito de que nos festejos do centenário, os estudantes estivessem familiarizados com o hino da cidade. Contudo, em meio às contendas geradas pelo concurso para escolha de um novo hino, nos parece que houve um pacto de conformação na escolha do mesmo com relação ao antigo. No novo hino, com exceção de algumas modificações (a mais importante foi a inserção do cacau, pois o antigo hino não o mencionava), permaneciam os elementos centrais contidos no hino antigo: bravura e atuação pioneira, bem como alusão à ideia de progresso.

Dentre as versões submetidas à votação popular, em 2010, a versão escolhida pela maioria dos votantes, foi o hino de autoria de Carlos Correia Oliveira, com 39\% do total dos votos, que não passava de uma leitura um pouco atualizada do antigo hino de Itabuna. Na cerimônia de oficialização da eleição, Carlos Correia Oliveira proferiu, às autoridades municipais, as seguintes palavras: “Não fui 
eu quem venceu, mas sim, o povo de Itabuna que terá sua história perpetuada". ${ }^{80}$

Assim como no hino antigo, o novo trazia simbolicamente dois aspectos principais da construção da identidade itabunense: a figura do pioneiro e a ideia de uma história progressista:

Lá na mata, o ouro fruto,

O seu brilho atraiu

Homens bravos, corajosos,

A natureza... O desafio!

Com o machado, o homem na mata

Ressoa o grito voraz da vitória!

Tabocas! Tabocas! Tabocas...

Itabuna tu és agora! ${ }^{81}$

O hino, como era de se esperar, deixava em evidência a atualização de uma memória coletiva da cidade, na qual não existia espaço para outros atores que não fossem os ditos pioneiros da região. Eram apenas eles, a mata e o desafio de vencê-la. A ideia progressista gestada pela narrativa da década de 1960, de que ao futuro da cidade estava reservado o progresso industrial, foi atenuada, visto que, como já refletimos, aquela narrativa soava como uma alternativa para pacificar os ânimos e insatisfações diante do fracasso do cacau, naquele momento, o que já não atendia à realidade de 2010 . No atual hino, a referência ao papel da indústria na cidade aparece apenas em uma frase: "No comércio, na indústria... Sua força!". Quando

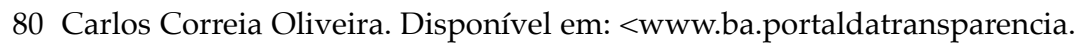
com.br>. Acesso em: 9 dez. 2014, às 22: 57.

81 Autoria de Carlos Correia Oliveira. Divulgação oficial da eleição do Hino de Itabuna: Diário Oficial do Município: 4 de junho de 2010, ano II, $\mathrm{n}^{\circ}$ 365. Disponível em: $<$ www.ba.portaldatransparencia.com.br $>$. Acesso em: 9 dez. 2014, às 23:40. 
na antiga versão, o apelo progressista com ênfase na indústria ressaltava:

[...] Seu progresso bem traduz

O que em palavra diria

Oh! Rainha da Bahia.

Sua fonte de riqueza

No Estado é sem rival

E em muito breve terá

Inteirando sua beleza

Grande parque industrial. ${ }^{82}$

Desse modo, diante do prometido "parque industrial" que não chegou, a ênfase dada ao aspecto industrial para definir a potência econômica de Itabuna foi retirada da versão atual do hino. Em contrapartida, foi reforçada a atuação dos "pioneiros". Em nosso entender, essa história de origem atinge uma coesão na memória coletiva, à medida que ganha significado amplo e formal na trajetória histórica da cidade.

$\mathrm{Na}$ comparação entre os dois hinos, um aspecto que consideramos dos mais interessantes é o seguinte: o primeiro hino não faz referência alguma ao cacau e prioriza a vocação industrial da cidade; já a versão atual atenua a ideia de progresso industrial para Itabuna e coloca no centro da letra do hino o cacau:

Lá na mata, o ouro fruto,

O seu brilho atraiu

Homens bravos, corajosos,

A natureza... O desafio!

82 Autoria de Nicolau Midlej. Blog Itabuna Centenária. Disponível em: <cemanosdeitabuna.ning.com>. Acesso em: 10 dez. 2014, às 00:09. 
$[\ldots]$

O fruto ouro nos olhos, na alma!

Do Cachoeira, a cidade se expandindo!

Em 2010, quando se deu a comemoração do centenário de Itabuna, parecia importante falar do cacau, falar dos ditos pioneiros e seu papel de vanguarda. Essa parecia ser a história que se desejava incutir nos novos e perpetuar através da memória coletiva oficial. Além disso, a Itabuna de 2010 era uma cidade que já não vivia do cacau, sua economia girava, principalmente, em torno da oferta de serviços; do mercado terceirizado e do comércio, que passaram a atender os pequenos municípios vizinhos. Ela não carregava mais o peso que representava o fracasso do cacau para uma região monocultora, como o era na década de 1960. Podia-se falar novamente do cacau sem constrangimento social para a sua "antiga" elite.

Analisando a produção memorialista amparada em uma série de aparatos de legitimação da sua narrativa, propusemos, até aqui, a reflexão de um duplo movimento da escrita memorialista: lembrar os sergipanos e esquecer os índios, na construção do que chamamos de uma memória coletiva oficial sobre a fundação de Itabuna e sua história. Nos próximos capítulos, tentaremos analisar a história de parte do sul da Bahia, durante o século XIX, hoje conhecida como Itabuna, por outros vieses, que possibilitem acolher e pensar outras variantes e outros atores dessa história.

Como frisamos no início deste capítulo, nossa pretensão não foi travar uma batalha entre mito e história; ao contrário, buscamos demonstrar como a história se transformou em mito, como o mito se entranhou na trajetória política e intelectual da cidade. Nesses últimos parágrafos, contudo, consideramos pertinente elencar algumas observações acerca da narrativa histórica, que é o lugar de fala do 
presente estudo e, assim, acentuar o nosso posicionamento teórico-metodológico delimitado nos capítulos seguintes.

Carlo Ginzburg observa que os historiadores, há algumas décadas, se ocuparam em discutir muito sobre "os ritmos da história", mas pouco ou nada sobre os "ritmos da narrativa histórica" 83 , o que suscitou infindáveis críticas internas e externas da disciplina. Nesse sentido, além do próprio Ginzburg, outros estudiosos, como Paul Ricoeur, procuraram não apenas encontrar respostas às críticas recebidas, mas, principalmente, pensar o caráter particular da narrativa do conhecimento histórico.

Paul Ricoeur, enfrentando o tema da narrativa histórica em face da memória, propõe analisar o trabalho da operação historiográfica em três fases: a fase documental, a fase explicativa/compreensiva e a fase reconstrutiva. De acordo com ele, é na fase reconstrutiva que se tem "a intenção de representar em verdade as coisas passadas, pela qual se define em face da memória o projeto cognitivo e prático da história tal como a escrevem os historiadores profissionais" ${ }^{84}$. Em "representação e narração", o autor problematiza: que diferença separa a história e a ficção, se ambas narram? ${ }^{85} \mathrm{~A}$ resposta não é simples e muitos profissionais da história, da filosofia e da literatura se envolveram neste debate após os acirramentos gestados a partir da "virada linguística", em meados do século XX. Para Ricoeur, uma das saídas parece estar na compreensão do que sejam representação e acontecimento.

Novamente, outro questionamento: "Mas o que vem a ser um acontecimento depurado de qualquer conexão

83 GINZBURG, Carlo. O fio e os rastros: verdadeiro, falso, fictício. São Paulo: Companhia das Letras, 2007, p. 321.

84 RICOEUR, Paul. Op., cit., p. 147.

85 Idem, p. 253. 
narrativa?" 86 Ele responde: não há uma ligação direta entre a forma narrativa e o acontecimento tal como de fato foi produzido. Para o autor, a ligação entre narrativa e acontecimento se dá de forma indireta, através da explicação e "aquém desta, através da fase documental, que remete, por sua vez, ao testemunho e ao crédito dado à palavra alheia" ${ }^{87}$.

$\mathrm{O}$ acontecimento é o referente da representação do passado operada pela narrativa historiográfica. Paul Ricoeur lembra que "foi da teoria literária que veio a contestação em nome da disjunção entre a estrutura interna do texto e o real extratextual [...], é o modelo bipolar significante-significado, com exclusão do referente" ${ }^{88}$ Ricoeur frisa ser o efeito dessa assertiva literária devastadora para a narrativa da história, cuja diferença da narrativa literária ou ficcional se baseia na categoria referencial que a perpassa ${ }^{89}$. Sendo assim, não se tem a pretensão de apreender o passado na narrativa da história. Contudo, diferentemente do escritor ficcional, o historiador não trabalha apenas com a estrutura interna do texto, mas opera conjuntamente com a estrutura interna e com o real extratextual, pois

Diferentemente do pacto entre um autor e um leitor de ficção que se baseia na dupla convenção de suspender a expectativa de qualquer descrição de um real extralinguístico e, em contrapartida, reter o interesse do leitor, o autor e o leitor de um texto histórico convencionam que se tratará de situações, acontecimentos, encadeamentos, persona-

86 RICOEUR, Paul. Op., cit., p. 254.

87 Idem, p. 256.

88 Idem, p. 259.

89 Idem, ibidem. 
gens que existiram realmente anteriormente, isto é, antes que tenham sido relatados ${ }^{90}$.

Esforçamo-nos, até aqui, no sentido de tecer algumas reflexões consideradas importantes acerca da narrativa da memória de Itabuna da década de 1960, com um duplo olhar: perceber a construção do mito sergipano e o processo de invisibilização indígena empreendido naquela narrativa. Gostaríamos de frisar que, na história daquela parte do sul da Bahia, hoje conhecida como Itabuna, nem tudo era sergipano. Nessa direção, tentaremos demonstrar, a seguir, a atuação indígena na história da colonização da Cachoeira de Itabuna e na de Ferradas, ao longo do século XIX.

90 RICOEUR, Paul. Op., cit., p. 289. 